\title{
АНТИАГРЕГАНТНОЕ СРЕДСТВО С БИВАЛЕНТНЫМ МЕХАНИЗМОМ ДЕЙСТВИЯ
}

\section{А.А. Спасов', О.Н. Жуковская², А.Ф. Кучерявенко', П.М. Васильев', В.С. Сиротенко , К.А. Гайдукова', В.С. Сочнев ${ }^{2}$, Е.А. Гусаков ${ }^{2}$, Ю.А. Саяпин ${ }^{3}$, Т.А. Кузьменко ${ }^{2}$, Л.Н. Диваева ${ }^{2}$, А.С. Морковник ${ }^{2}$}

1Волгоградский Государственный Медицинский Университет Минздрава РФ, 400131, Россия, г. Волгоград, пл. Павших Борцов, 1;

${ }^{2}$ НИИ Физической и органической химии ЮФУ, 344090, Россия, г. Ростов-на- Дону, пр. Стачки, 194/2.

${ }^{3}$ ФГБУ «Федеральный исследовательский центр Южный научный центр РАН» (ЮНЦРАН).

DOI: 10.19163/MedChemRussia2021-2021-551_E-mail: aidakucheryavenko@yandex.ru

Ингибирование агрегации тромбоцитов играет важную роль в предотвращении тромбообразования, поэтому поиск, изучение и создание новых средств, блокирующих несколько путей активации тромбоцитарного звена гемостаза является важной задачей в решении данной проблемы.

В результате компьютерного поиска и экспериментального скрининга invitro было выявлено производное бензимидазола соединение РУ-891 (гидробромид 9-[2-(3,4-дигидроксифенил)-2-оксоэтил]-2,3-дигидроимидазо[1,2-а]бензимидазола), синтезированное в ФГАОУ ВО НИИФОХ ЮФУ.

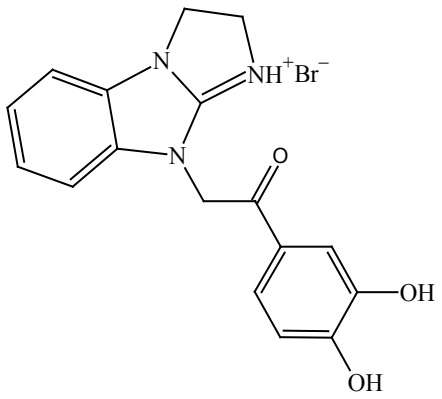

Разработаны лабораторный и технологический регламенты получения субстанции и лекарственной формы соединения РУ-891, проведена их стандартизация.

Соединение РУ-891 одновременно блокирует две мишени активации тромбоцитарного звена гемостаза - $22 \mathrm{Y}_{12}$ рецепторы тромбоцитов и синтез тромбоксана $\mathrm{A}_{2}$ и по влиянию на тромбогенный потенциал крови на различных моделях тромбозов превосходит ацетилсалициловую кислоту и клопидогрел.

В настоящее время завершен полный цикл доклинических исследований субстанции РУ-891 и лекарственной формы «Таблетки РУ-891, 270 мг», предназначенной для профилактики и лечении тромбообразования и подготовлен проект документов для проведения I фазы клинических исследований. 